\title{
Pelatihan Implemantasi dan Inovasi Kurikulum 2013 Paud di Lembaga Paud Kota Samarinda
}

\author{
Hanita \\ Universitas Widya Gama Mahakam Samarinda \\ nitahanita87@gmail.com
}

\begin{abstract}
Abstrak
Pengembangan profesionalisme menjadi dasar keahlian seorang pendidik. Tujuan pengembangan professional terdiri dari pengetahuan tentang isi pembelajaran, pengetahuan tentang pendidikan, pengetahuan professional, dan kualitas professional. Perkembangan yang tidak terlepas dari pendekatan yang sesuai dengan perkembangan peserta didik, dengan memahami anak-anak, praktik pengajaran yang sesuai dengan perkembangan dan budaya anak didik, serta kurikulum pembelajaran anak usia dini. Kurikulum memegang kunci dalam pendidikan, serta berkaiatan dengan penentuan arah, isi dan proses pendidikan yang menetukan macam dan kualifikasi lulusan suatu lembaga. Pentingnya kurikulum dalam kegiatan pendidikan maka dalam penyusunanya memerlukan landasan yang kuat melalui pemikiran - penelitian yang mendalam dan salah satu upaya pengembangan profesionalisme dan peningkatan keahlian pendidik dalam pendidikan anak usia dini. Kurikulum merupakan rancangan pendidikan yang memiliki peran strategis karena seluruh kegiatan berpusat pada kurikulum. Dalam hal ini maka kurikulum merupakan hal yang penting dipahami oleh pendidik yaitu pemahaman terhadap kurikulum 2013 yang tercantum dalam Peraturan Menteri Pendidikan dan Kebudayaan Republik Indonesia No. 137 tahun 2014 tentang Standar Nasional Pendidikan Anak Usia Dini yang salah satunya membahasa tentang Standar Proses yang mencakup Perencanaan pembelajaran, pelaksanaan pembelajaran, Evaluasi Pembelajaran dan Pengawasan Pembelajaran dalam hal ini terkait tentang standar kurikulum PAUD. Dalam Peraturan Menteri Pendidikan dan Kebudayaan Republik Indonesia No. 146 tahun 2014 tentang Kurikulum 2013 Pendidikan Anak Usia Dini.
\end{abstract}

Kata Kunci : Implemantasi dan Inovasi Kurikulum 2013 PAUD 


\section{Jurnal Abdimas Mahakam \\ https://journal.uwgm.ac.id/index.php/abdimasmahakam \\ Online ISSN : 2549-5755 \\ Januari 2017, Vol.1 No. 1}

\section{Pendahuluan}

Seorang pendidik anak usia dini harus memiliki pengetahuan tentang isi pembelajaran, pendidikan, dan profesional serta kualitas profesional yang diperlukan untuk mengajar dan menjalankan program-program sehingga semua anak didik dapat belajar dengan baik.

Pengembangan profesionalisme menjadi dasar keahlian seorang pendidik. Tujuan pengembangan professional terdiri dari pengetahuan tentang isi pembelajaran, pengetahuan tentang pendidikan, pengetahuan professional, dan kualitas professional. Perkembangan yang tidak terlepas dari pendekatan yang sesuai dengan perkembangan peserta didik, dengan memahami anak-anak, praktik pengajaran yang sesuai dengan perkembangan dan budaya anak didik, serta kurikulum pembelajaran anak usia dini.

Sebagaimana Nana Syaodih Sukmadinata menyatakan Kurikulum memegang kunci dalam pendidikan, serta berkaiatan dengan penentuan arah, isi dan proses pendidikan yang menetukan macam dan kualifikasi lulusan suatu lembaga. Pentingnya kurikulum dalam kegiatan pendidikan maka dalam penyusunanya memerlukan landasan yang kuat melalui pemikiran - penelitian yang mendalam dan salah satu upaya pengembangan profesionalisme dan peningkatan keahlian pendidik dalam pendidikan anak usia dini.

Kurikulum merupakan rancangan pendidikan yang memiliki peran strategis karena seluruh kegiatan berpusat pada kurikulum. Dalam hal ini maka kurikulum merupakan hal yang penting dipahami oleh pendidik yaitu pemahaman terhadap kurikulum 2013 yang tercantum dalam Peraturan Menteri Pendidikan dan Kebudayaan Republik Indonesia No. 137 tahun 2014 tentang Standar Nasional Pendidikan Anak Usia Dini yang salah satunya membahasa tentang Standar Proses yang mencakup Perencanaan pembelajaran, pelaksanaan pembelajaran, Evaluasi Pembelajaran dan Pengawasan Pembelajaran dalam hal ini terkait tentang standar kurikulum PAUD. Dalam Peraturan Menteri Pendidikan dan Kebudayaan Republik Indonesia No. 146 tahun 2014 tentang Kurikulum 2013 Pendidikan Anak Usia Dini. Dengan demikian, membicarakan kurikulum 2013 PAUD merupakan suatu hal yang perlu dipahami secara mendalam oleh para pendidik, maka pelatihan ini merupakan sarana untuk memberikan pemahaman dan praktik kurikulum 2013 PAUD. Sealin itu juga pemahaman para pendidik dalam praktik kurikulum 2013 PAUD masih kurang. 


\section{Jurnal Abdimas Mahakam}

https://journal.uwgm.ac.id/index.php/abdimasmahakam

Online ISSN : 2549-5755

Januari 2017, Vol.1 No. 1

\section{Metode}

\section{Waktu Dan Tempat}

Adapun pelaksanaan pengabdian masyarakat ini diberiakan kepada para pendidik di ruang C01 Universitas Widya Gama Mahakam Samarinda. Berkenaan waktu pelaksanaanya pada bulan 16 September 2017.

\section{Struktur Program}

Struktur program kegiatan pelaihan bagi guru pendidikan anak usia dini sebagai berikut :

\begin{tabular}{llll}
\hline No & Program & \multicolumn{1}{c}{ Materi Seminar dan Workshop } & $\begin{array}{c}\text { Alokasi } \\
\text { Waktu }\end{array}$ \\
\hline 1. & Pokok & Kurikulum 2013 PAUD & 90 menit \\
2. & Penunjang & Prektek Aplikasi pembuatan kurikulum 2013 & 120 menit \\
& & PAUD
\end{tabular}

Tabel.1. program Kegiatan

\section{Susunan Acara}

Susunan Aacara Kegiatan sebagai berikut :

\begin{tabular}{lcll}
\hline No & \multicolumn{1}{c}{ Waktu } & \multicolumn{1}{c}{ Kegiatan } & \multicolumn{1}{c}{ Pengurus } \\
\hline 1. & $08.00-09.00$ wita & Regristrasi Ulang Peserta & Team \\
2. & $09.00-09.05$ wita & Pembukaan & MC Acara \\
3. & $09.05-09.15$ wita & Pembacaan Doa & Team Panitia \\
4 & $09.15-10.45$ wita & Pelatihan I & Kurikulum 2013 \\
& & & PAUD \\
5. & $10.45-11.15$ wita & Pelatihan II & Aplikasi \\
& & & Kurikulum 2013 \\
& & & PAUD \\
6. & $11.15-$ selesai wita & Penutup dan pembagian & \\
& & Sertifikat & \\
\hline
\end{tabular}

Tabel .2. Susunan Acara

4. Skenario Kegiatan 


\section{Jurnal Abdimas Mahakam}

https://journal.uwgm.ac.id/index.php/abdimasmahakam

Online ISSN : 2549-5755

Januari 2017, Vol.1 No. 1

Adapun Kegiatan ini memiliki skenario Kegiatan, sebagai berikut :

1. Input
a. Kurikulum 2013 PAUD
b. Aplikasi Kurikulum 2013 PAUD
c. Modul Materi
d. Contoh Pembuatan Porogram Semester, Program Mingguan dan Program Harian

2. Proses
a. Mengkaji tentang Kurikulum 2013 PAUD
b. Mengkaji tentang Aplikasi Kurikuum 2013 PAUD

3. Output

a. Meningkatkan pemahaman dan pengetahuan peserta tentang Kurikulum 2013 PAUD

b. Meningkatkan pemahaman dan pengetahuan peserta tentang Aplikasi Kurikulum 2013 PAUD

\section{Metode Pelatihan}

Metode yang digunakan anatara lain : Ceramah, Diskusi, Praktek. Selain itu juga menyesuaikan dengan karakteristik peserta, waktu, serta sarana yang tersedia.

\section{Fasilitator}

Nara sumber dalam pelatihan ini adalah Hanita, M.Pd

\section{Hasil Dan Pembahasan}

Konsep Dasar Kurikulum 2013 Paud

Dijelaskan Peraturan Menteri Pendidikan Dan Kebudayaan Republik Indonesia Nomor 146 Tahun 2014 Tentang Kurikulum 2013 Pendidikan Anak Usia Dini yaitu :

1. Kurikulum PAUD disebut Kurikulum 2013 Pendidikan Anak Usia Dini. 


\section{Jurnal Abdimas Mahakam \\ https://journal.uwgm.ac.id/index.php/abdimasmahakam \\ Online ISSN : 2549-5755 \\ Januari 2017, Vol.1 No. 1}

2. Kurikulum 2013 Pendidikan Anak Usia Dini mengacu pada Standar Nasional Pendidikan Anak Usia Dini.

3. Kurikulum 2013 Pendidikan Anak Usia Dini: a. Kerangka Dasar Kurikulum; b. Struktur Kurikulum; c. Pedoman Deteksi Dini Tumbuh Kembang Anak; d. Pedoman Pengembangan Kurikulum Tingkat Satuan Pendidikan; e. Pedoman Pembelajaran; f. Pedoman Penilaian; dan g. Buku-buku Panduan Pendidik.

Kompetensi Inti PAUD merupakan gambaran pencapaian Standar Tingkat Pencapaian Perkembangan Anak pada akhir layanan PAUD usia 6 (enam) tahun yang dirumuskan secara terpadu dalam bentuk:
a. Kompetensi Inti Sikap Spiritual (KI-1)
b. Kompetensi Inti Sikap Sosial (KI-2)
c. Kompetensi Inti Pengetahuan (KI-3)
d. Kompetensi Inti Keterampilan (KI-4).

Selanjutnya Kompetensi Dasar merupakan tingkat kemampuan dalam konteks muatan pembelajaran, tema pembelajaran, dan pengalaman belajar yang mengacu pada Kompetensi Inti, merupakan penjabaran dari Kompetensi Inti dan terdiri atas:
a. Kompetensi Dasar sikap spiritual
b. Kompetensi Dasar sikap sosial
c. Kompetensi Dasar pengetahuan
d. Kompetensi Dasar keterampilan.

Kompetensi Dasar dapat dijabarkan lebih lanjut dalam indikator pencapaian perkembangan anak. Program pembelajaran Pendidikan Anak Usia Dini salah satu bentuk penyelanggaraan pendidikan yang menitik beratkan pada peletakan dasar kerah pertumbuhan dab perkembangan fisik, kecerdasan, sosialemosi, bahasa dan komunikasi yang disesuaikan dengan keunikan dan tahap-tahap perkembangan yang dilalui oleh anak usia dini. Dalam Pasal 5 menyebutkan Struktur kurikulum PAUD memuat program-program pengembangan 


\section{Jurnal Abdimas Mahakam \\ https://journal.uwgm.ac.id/index.php/abdimasmahakam \\ Online ISSN : 2549-5755 \\ Januari 2017, Vol.1 No. 1}

yang mencakup: a. nilai agama dan moral; b. fisik-motorik; c. kognitif; d. bahasa; e. sosialemosional; dan f. seni.

Standar PAUD terdiri atas: a. Standar Tingkat Pencapaian Perkembangan Anak; b. Standar Isi; c. Standar Proses; d. Standar Penilaian; e. Standar Pendidik dan Tenaga Kependidikan; f. Standar Sarana dan Prasarana; g. Standar Pengelolaan; dan h. Standar Pembiayaan yang tertera pada Peraturan Menteri Pendidikan Dan Kebudayaan Republik Indonesia Nomor 137 Tahun 2014 Tentang Standar Nasional Pendidikan Anak Usia Dini Pasal 2. Dalam Peraturan Menteri ini yang dimaksud dengan:

1. Standar Nasional Pendidikan Anak Usia Dini selanjutnya disebut Standar PAUD adalah kriteria tentang pengelolaan dan penyelenggaraan PAUD di seluruh wilayah hukum Negara Kesatuan Republik Indonesia.

Standar PAUD berfungsi sebagai:

a. dasar dalam perencanaan, pelaksanaan, pengawasan, dan tindak lanjut pendidikan dalam rangka mewujudkan PAUD bermutu

b. acuan setiap satuan dan program PAUD untuk mewujudkan tujuan pendidikan nasional

c. dasar penjaminan mutu PAUD.

2. Standar Tingkat Pencapaian Perkembangan Anak Usia Dini selanjutnya disebut STPPA adalah kriteria tentang kemampuan yang dicapai anak pada seluruh aspek perkembangan dan pertumbuhan, mencakup aspek nilai agama dan moral, fisik-motorik, kognitif, bahasa, sosial-emosional, serta seni.

a. Tingkat Pencapaian Perkembangan Anak merupakan pertumbuhan dan perkembangan anak yang dapat dicapai pada rentang usia tertentu.

b. Pertumbuhan anak merupakan pertambahan berat dan tinggi badan yang mencerminkan kondisi kesehatan dan gizi yang mengacu pada panduan pertumbuhan anak dan dipantau menggunakan instrumen yang dikembangkan oleh Kementerian Kesehatan yang meliputi Kartu Menuju Sehat (KMS), Tabel BB/TB, dan alat ukur lingkar kepala.

c. Perkembangan anak merupakan integrasi dari perkembangan aspek nilai agama dan moral, fisik-motorik, kognitif, bahasa, dan sosial-emosional, serta seni. 


\section{Jurnal Abdimas Mahakam \\ https://journal.uwgm.ac.id/index.php/abdimasmahakam \\ Online ISSN : 2549-5755 \\ Januari 2017, Vol.1 No. 1}

d. Perkembangan merupakan perubahan perilaku yang berkesinambungan dan terintegrasi dari faktor genetik dan lingkungan serta meningkat secara individual baik kuantitatif maupun kualitatif.

e. Pencapaian pertumbuhan dan perkembangan anak yang optimal membutuhkan keterlibatan orang tua dan orang dewasa serta akses layanan PAUD yang bermutu.

3. Standar Isi adalah kriteria tentang lingkup materi dan kompetensi menuju tingkat pencapaian perkembangan yang sesuai dengan tingkat usia anak.

a. Lingkup materi Standar Isi meliputi program pengembangan yang disajikan dalam bentuk tema dan sub tema.

b. Tema dan sub tema disusun sesuai dengan karakteristik, kebutuhan, tahap perkembangan anak, dan budaya lokal.

c. Pelaksanaan tema dan sub tema dilakukan dalam kegiatan pengembangan melalui bermain dan pembiasaan.

d. Tema dan sub tema dikembangkan dengan memuat unsur-unsur nilai agama dan moral, kemampuan berpikir, kemampuan berbahasa, kemampuan sosial-emosional, kemampuan fisik-motorik, serta apresiasi terhadap seni.

4. Standar Proses adalah kriteria tentang pelaksanaan pembelajaran pada satuan atau program PAUD dalam rangka membantu pemenuhan tingkat pencapaian perkembangan yang sesuai dengan tingkat usia anak.

a. Perencanaan pembelajaran dilakukan dengan pendekatan dan model pembelajaran yang sesuai dengan kebutuhan, karakteristik anak, dan budaya lokal.

b. Perencanaan pembelajaran meliputi:

1) program semester (Prosem);

2) rencana pelaksanaan pembelajaran mingguan (RPPM); dan

3) rencana pelaksanaan pembelajaran harian $(\mathrm{RPPH})$.

c. Perencanaan pembelajaran disusun oleh pendidik pada satuan atau program PAUD.

5. Standar Penilaian adalah kriteria tentang penilaian proses dan hasil pembelajaran dalam rangka mengetahui tingkat pencapaian yang sesuai dengan tingkat usia anak. 


\section{Jurnal Abdimas Mahakam \\ https://journal.uwgm.ac.id/index.php/abdimasmahakam \\ Online ISSN : 2549-5755 \\ Januari 2017, Vol.1 No. 1}

a. Prinsip penilaian mencakup prinsip edukatif, otentik, obyektif, akuntabel, dan transparan yang dilakukan secara terintegrasi, berkesinambungan, dan memiliki kebermaknaan.

b. Prinsip edukatif merupakan penilaian yang mendorong anak meraih capaian perkembangan yang optimal.

c. Prinsip otentik merupakan penilaian yang berorientasi pada kegiatan belajar yang berkesinambungan dan hasil belajar yang mencerminkan kemampuan anak saat melaksanakan kegiatan belajar.

d. Prinsip objektif merupakan penilaian yang didasarkan pada indikator capaian perkembangan serta bebas dari pengaruh subjektivitas penilai dan yang dinilai.

e. Prinsip akuntabel merupakan pelaksanaan penilaian sesuai dengan prosedur dan kriteria yang jelas, serta ditetapkan pada awal pembelajaran.

f. Prinsip transparan merupakan penilaian prosedur dan hasil penilaian yang dapat diakses oleh semua pemangku kepentingan.

6. Standar Pendidik dan Tenaga Kependidikan adalah kriteria tentang kualifikasi akademik dan kompetensi yang dipersyaratkan bagi pendidik dan tenaga kependidikan PAUD.

7. Standar Sarana dan Prasarana adalah kriteria tentang persyaratan pendukung penyelenggaraan dan pengelolaan pendidikan anak usia dini secara holistik dan integratif yang memanfaatkan potensi lokal.

8. Standar Pengelolaan adalah kriteria tentang perencanaan, pelaksanaan, dan pengawasan kegiatan pendidikan pada tingkat satuan atau program PAUD.

9. Standar Pembiayaan adalah kriteria tentang komponen dan besaran biaya personal serta operasional pada satuan atau program PAUD.

10. Pendidikan Anak Usia Dini adalah upaya pembinaan yang ditujukan kepada anak sejak lahir sampai usia 6 (enam) tahun yang dilakukan melalui pemberian rancangan pendidikan untuk membantu pertumbuhan dan perkembangan jasmani dan rohani agar anak memiliki kesiapan dalam memasuki pendidikan lebih lanjut.

11. Satuan atau program PAUD adalah layanan PAUD yang dilaksanakan pada suatu lembaga pendidikan dalam bentuk Taman Kanak-kanak (TK)/Raudatul Athfal 


\section{Jurnal Abdimas Mahakam \\ https://journal.uwgm.ac.id/index.php/abdimasmahakam \\ Online ISSN : 2549-5755 \\ Januari 2017, Vol.1 No. 1}

(RA)/Bustanul Athfal (BA), Kelompok Bermain (KB), Taman Penitipan Anak (TPA), dan Satuan PAUD Sejenis (SPS).

12. Kurikulum PAUD adalah seperangkat rencana dan pengaturan mengenai tujuan, isi, dan bahan pengembangan serta cara yang digunakan sebagai pedoman penyelenggaraan kegiatan pengembangan untuk mencapai tujuan pendidikan tertentu.

13. Pembelajaran adalah proses interaksi antar anak didik, antara anak didik dan pendidik dengan melibatkan orangtua serta sumber belajar pada suasana belajar dan bermain di satuan atau program PAUD.

14. Menteri adalah menteri yang menyelenggarakan urusan pemerintahan di bidang pendidikan.

Kurikulum 2013 Pendidikan Anak Usia Dini dirancang dengan berdasarkan karakteristik pendidikan anak usia dini anatara lain :

1. Mengoptimalkan perkembangan anak yang meliputi: aspek nilai agama dan moral, fisikmotorik, kognitif, bahasa, sosial emosional, dan seni yang tercermin dalam keseimbangan kompetensi sikap, pengetahun, dan keterampilan

2. Menggunakan pembelajaran tematik dengan pendekatan saintifik dalam pemberian rangsangan pendidikan

3. Menggunakan penilaian autentik dalam memantau perkembangan anak

4. Memberdayakan peran orang tua dalam proses pembelajaran.

Dari hasil penjabaran tentang kurikulum 13 pendidikan anak usia dini bertujuan untuk mendorong dan mengembangkan potensi dengan memberikan stimulus sesuai dengan kemampuan dan tahap perkembangan anak, memiliki kemampuan mental sosial emosi yang baik serta kesiapan anak untuk menempuh pendidikan selanjutny, yang dilaksanakan berdasarkan acuan dari Peraturan Menteri Pendidikan dan Kebudayaan RI No.137 tahun 2014 Standar Nasional PAUD dan No. 146 tahun 2014 tentang kurikulum 2013 PAUD.

\section{Simpulan dan Rekomendasi}

Pelaksanaan peraturan tentang Peraturan Menteri Pendidikan dan Kebudayaan RI No.137 tahun 2014 Standar Nasional PAUD dan No. 146 tahun 2014 tentang kurikulum 2013 PAUD, upaya mengembangkan dan menyempurnakan kurikulum sebelumnya. Dengan maksud untuk 


\section{Jurnal Abdimas Mahakam \\ https://journal.uwgm.ac.id/index.php/abdimasmahakam \\ Online ISSN : 2549-5755 \\ Januari 2017, Vol.1 No. 1}

meningkatkan kualitas pembelajaran pada pendidikan anak usia dini yang ada di Indonesia terutama di Lembaga PAUD yang ada di Samarinda.

Kurikulum memegang kunci dalam pendidikan, serta berkaiatan dengan penentuan arah, isi dan proses pendidikan yang menetukan macam dan kualifikasi lulusan suatu lembaga. Pentingnya kurikulum dalam kegiatan pendidikan maka dalam penyusunanya memerlukan landasan yang kuat melalui pemikiran - penelitian yang mendalam dan salah satu upaya pengembangan profesionalisme dan peningkatan keahlian pendidik dalam pendidikan anak usia dini.

Hal ini juga bertujuan untuk meningkatkan kemampuan guru dalam mengajar dan kretivitas dalam upaya perkembangan anak yang meliputi lingkup perkembangan bahasa, kognitif dan fisik. 


\section{Jurnal Abdimas Mahakam}

https://journal.uwgm.ac.id/index.php/abdimasmahakam

Online ISSN : 2549-5755

Januari 2017, Vol.1 No. 1

\section{Daftar Pustaka}

Mentri Pendidikan dan Kebudayaan RI, 2014. Standar Nasional PAUD. Peraturan MenteriPendidikan dan Kebudayaan RI No.137 Th 2014.

Mentri Pendidikan dan Kebudayaan RI, 2014. Kurikulum 2013 PAUD. Peraturan MenteriPendidikan dan Kebudayaan RI No.146 Th 2014.

Suyadi \& Dahlia, 2014. Implementasi dan Inovasi Kurikulum PAUD 2013 Program Pembelajaran Berbasis Multiple Intelligences. Bandung : Rosda

Susanto, Ahmad.2017. Pendidikan Anak Usia Dini (Konsep dan Teori). Jakarta : Bumi Aksara. 